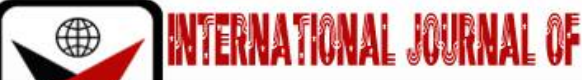

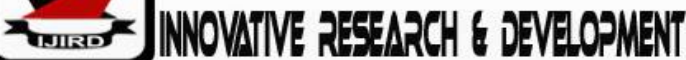

ISSN 2278-0211 (Online)

\section{Time Management Competencies and Practices of Enugu State Primary School Head Teachers in Knowledge and Learning Management, Nigeria}

Obineme, Patience .o
Lecturer, Department of Educational Management and Policy,
Nnamdi Azikiwe University Awka, Nigeria
Dr. Ven.John Nweke
Lecturer, Department of Educational Management and Policy,
Nnamdi Azikiwe University Awka, Nigeria
Chime, Gladys .0
Lecturer, Department of Educational Management and Policy,
Nnamdi Azikiwe University Awka, Nigeria
Loveline B Ekweogu
Lecturer, Department of Educational Management and Policy,
Nnamdi Azikiwe University Awka, Nigeria

\begin{abstract}
:
This study is based on time competencies and practices of Enugu state primary school head teachers in knowledge and learning management. The study adopted the descriptive survey design. The area of study for this research is Enugu state. 732 head teachers and 11, 782 primary school teachers in Enugu state formed the population of the study. Multi stage procedure, purposive and simple random sampling were adopted in selecting samples for the study. Instrument used for data collection was a 28 item questionnaire items with sections A and B. The instruments were divided into two, one for head teachers, and the other for teachers. The one for head teachers was tagged Time Management Competencies and Practice among Head teachers in Knowledge and Learning Management (TMCPHKLM); while the one for teachers tagged Extent Head teachers Practice Time Management Competencies for Knowledge and Management (EHPTMCKM). The instruments were validated by three experts. The reliability coefficient was determined using Cronbach Alpha reliability coefficient technique which gave coefficient of 0.76, 0.74, for cluster A and $B$ which gave a total value of 0.75 respectively. Analysis was done using arithmetic and standard deviation to answer the two research questions while t-test was used in testing the hypothesis on .05 degree. Findings show that primary school head teachers in Enugu state practice time management by assigning roles to pupils and teachers to ensure that school programs are carried out on time. These programmes include environmental cleaning, morning devotion, sticking to time table, and extracurricular activities. Based on these findings, it was recommended among all that head teachers should be consistent in management of time in their schools as this will be emulated by teachers who will inturn ensure that learning is effectively managed in the $21^{\text {st }}$ century.
\end{abstract}

Keywords: Time management, head teacher, learning management

\section{Introduction}

Education is generally regarded as one of the tools to aid improvement in the quality of human life and in the progress of the society in genl. It has also been seen as a good way of reducing the existing gap between the members of the society who are rich and poor. Education is considered the cornerstone for meaningful and sustainable growth, development and achievement in art, science, and technology. It is also affirmed worldwide as catalyst for achieving socioeconomic, scientific, and technological development (Abiogu, 2014). Formal education occurs in schools from preprimary/primary level to tertiary level; each been managed by an administrative head. In primary schools, the manager and administrative leader at this level of education is the head teacher.

The head teacher is the chief teacher and administrator of a primary school. Chiaha (2013) asserts that the head teacher, comparable to a school principal is the most senior teacher, leader and manager of a school. He or she is part of a divisional administrative team whose function is to support and assist the school in meeting the overall objectives of the division and the needs of individual learner. Among the major characteristics that makes the head teacher competence in his job is being conscious of time.Despite the type of activity to be performed by the head teacher, time is the crucial 
resource first to be considered. From primordial to modern administrative settings challenged by technological innovations, time still remains the major determinant of successful or unsuccessful completion of task. Therefore, an aspect that proves that a school head is diligent to duty is the way he manages time in school.

Time management is an aspect of head teachers competence and practice when dispensing their duties. Time management according to Zafarillah, Mumtaz, Uzma, Abida and Hum (2016) means the maximum use of time for productivity and achievement. It is concerned with the management of schedules of work with advanced planning, organizing, and implementation in order to achieve the aims and objectives of the school. The head teacher resumes to school on time and on daily basis, ensures that teachers on duty coordinates activities starting from getting the school environment tidy, assembling children for morning devotion, and ensuring that pupils begin learning at appropriate time. According to Lydiah and Nasongo (2009), an effective school head teacher ensures that he employs organizational skills which lead to effective teaching resulting into high academic achievement.

Jason, Susan and Hajime (2015) identified four ways administrators can apply time management principles in school administration. They are: planning, organizing, implementing and evaluating. For planned school time, Lara in Ugwulashi (2012) states that 'the time we have depends on the time we use'. In order to manage time successfully, administrators must have self-knowledge and set out goals to achieve. In school organizations, time is managed through the use of time table. Time table is a specific arrangement of time scheduled according to specific activity. In typical school situation, time is arranged for various activities to be performed ranging from opening and closing of devotion, classroom work, agricultural work, craft, examination, labour, sports, recreation, prep, dining and closure etc. all these are ways of planned school time.

Organizing is the next stage after successful planning. It involves ordinary arrangement of all planned activities. At this stage of time management, organizing has to do with time in bringing all the required resources together. It deals with assembling of resources for facilitating the easy realization of set out goals. Here roles are assigned to staff according to targets. When time is planned and organized, they are easily implemented by teachers, administrators and other relevant human resource; while what was implemented must be evaluated to show efficient use in accomplishing set objectives and goals. This helps to find out the workability of planned activities whether they can be accomplished within the time allocated to them. For example, a teacher covers the class syllabus planned for 10weeks before the end of term examination is administered to the students established that the period of teaching-learning has been effective on one hand. On the other hand, their performance in the weekly test or examination may proof weather the whole time served in purpose because poor performance may include wasted period (Ugwulashi, 2012).

Some authorities have also revealed that time management competencies as practices of head teachers paves way for acquisition and knowledge by pupils and learning in genl. However, knowledge acquired by pupils in schools in form of academic performance is an indication that learning took place because good performance after a period of learning and evaluation indicates change in previous behavior (Nwamuo, 2010). When learning leads to change in behavior because of such learning, such learning atmosphere could be managed for academic achievement of future children that may enroll in a school. The ways head teachers manage the time in school go a long way in determining the survival and management of learning. This century could be termed learning because nations across the globe are utilizing available human and material resources at their disposal to advance their education especially as it concerns science and technology. The researcher believes that time management competencies among head teachers could help pupils benefit from in school and enhance management of learning. This study therefore is poised to examine time management competencies and practices of Enugu state Primary school head teacher as it contains knowledge and learning management.

\subsection{Statement of the Problem}

It's a truism that the head teacher of a school is the manager and leader of a primary school. He issues out instructions, guidelines and also, monitors implementation of instructions for the achievement of stated academic goals. By this role, he manages both human and material resources at his disposal. It is however important to note that an aspect of the head teachers that makes him competent to manage the school is time management. When time is managed, all other activities run smoothly and thus, everybody is carried along. Problems encountered in primary schools today as observed are partly caused by poor management of time by head teachers and this as observed, gentle rancor between teachers and their heads. For instance, a head teacher who comes to school late, leaves school on time without official assignment at the ministry nor fails to go around the school to ascertain level of compliance to instructions, timely resumption of teachers and pupils and teachers being consistency with time table attracts failure in his leadership. With these behaviors, one would agree that there is trace of the practice of what should be competencies in time management which is a way of managing learning. This lackadaisical attitude observed by some head teachers if not checked, would definitely metamorphose in teachers, lesser-faire attitude leading to collapse of instruction, academic imbalance, poor management of learning.

Based on this background, the researcher is faced with problem trying to identify what could be the impact of time management competencies and practice as it concerns Enugu state primary school head teachers in knowledge and learning management. This problem without a yet solution as it concerns primary schools in Enugu state becomes a gap this study intends to fill.

\subsection{Purpose of the Study}

The main purpose of this study is to examine time management competence $s$ and practices of Enugu state primary school head teachers in knowledge and learning Management. Specifically, this study seeks to; 
- $\quad$ Find out time management competencies of Enugu state primary school head teachers in knowledge and learning management.

- Examine the extent Enugu state primary school head teachers practices learning management competencies for knowledge and management.

\subsection{Research Questions}

The following research questions guided this study.

- What are the time management competencies of Enugu state primary school head teachers in knowledge and learning management?

- To what extent do Enugu state primary school head teachers practice time management competencies for knowledge and learning management?

\subsection{Hypothesis}

- Time management competencies of Enugu state primary school head teachers do not significantly aid knowledge and management of learning this.

- Opinions of male and female teachers do not significantly differ on extent head teacher's practice of competencies aids knowledge and management of learning in this.

\section{Methods}

The study adopted the descriptive survey design. The area of study was Enugu state. The population of the study comprises of 732 head teachers and 11, 782 primary school teachers and in Enugu state. Multi stage procedure was adopted in selecting sample for the study. Stage one, the researcher purposively selected 5 primary schools from the six education zones in Anambra state for the study. Stage two, from each of these schools, the researcher selects 3 head teachers, making a total of 90 head teachers selected as sample for the study. The researcher also selected from each school, 7 teachers from each school, making a total of 210 primary school teachers.

Instrument used for data collection was a 28 item questionnaire items which contains section $\mathrm{A}$ and $\mathrm{B}$. section $\mathrm{A}$ has 14 items for head teachers while section B has 14 items for primary school teachers. The instrument was divided into two, one for head teachers, the other for teachers. The one for head teachers was tagged Time Management Competencies and Practice among Head teachers in Knowledge and Learning Management (TMCPHKLME); while the one for teachers tagged Extent Head teachers Practice Time Management Competencies for Knowledge and Management (EHPTMCKME). The instruments were validated by three experts. The reliability coefficient was determined using Cronbach Alpha reliability coefficient technique which gave coefficient of $0.76,0.74$, for cluster A and B which gave a total value of 0.75 respectively. Analysis was done using arithmetic and standard deviation to answer the two research questions while t-test was used in testing the hypothesis on .05 degree.

\section{Results}

- Research question one: What are the time management competencies of Enugu state primary school head teachers in knowledge and learning management?

\begin{tabular}{|c|c|c|c|c|c|}
\hline $\begin{array}{l}\mathbf{S} / \\
\mathbf{N}\end{array}$ & ITEMS & $\mathbf{N}$ & $\overline{\mathbf{X}}$ & SD & Decision \\
\hline 1 & Mandating teachers to be in school on time. & 84 & 1.85 & 1.06 & Reject \\
\hline 2 & Assigning role of ringing the school bell to particular pupils & 84 & 3.14 & 0.62 & Accept \\
\hline 3 & Rotation of morning duty among teachers & 84 & 2.75 & 0.53 & Accept \\
\hline 4 & $\begin{array}{l}\text { Periodic notification of teachers on punctuality during lesson } \\
\text { periods. }\end{array}$ & 84 & 3.25 & 0.58 & Accept \\
\hline 5 & $\begin{array}{l}\text { Working with other head teachers to ensure that all staff } \\
\text { endorse their signature at attendance book on daily basis }\end{array}$ & 84 & 2.84 & 0.51 & Accept \\
\hline 6 & $\begin{array}{l}\begin{array}{l}\text { Appropriate placement of subjects on timetable to suit } \\
\text { learning }\end{array} \\
\end{array}$ & 84 & 3.04 & 0.57 & Accept \\
\hline 7 & $\begin{array}{l}\text { Ensuring that teachers chose of practical class is in-line with } \\
\text { the school time table. }\end{array}$ & 84 & 2.71 & 0.53 & Accept \\
\hline 8 & Ensuring that plays are only carried out during break period & 84 & 2.02 & 0.46 & Reject \\
\hline 9 & $\begin{array}{l}\text { Regulating and rotating influx of pupils inside the school } \\
\text { library }\end{array}$ & 84 & 2.96 & 0.56 & Accept \\
\hline 10 & Rotating days and periods pupils visit the school library & 84 & 2.78 & 0.53 & Accept \\
\hline 11 & Timely providing teachers with needed records & 84 & 3.15 & 0.62 & Accept \\
\hline 12 & $\begin{array}{l}\text { Involvement in internal supervision of teaching and non- } \\
\text { teaching staff }\end{array}$ & 84 & 3.34 & 0.53 & Accept \\
\hline 13 & Timely maintenance of material resources that aids teaching & 84 & 3.30 & 0.59 & Accept \\
\hline 14 & Regulating teacher's movement during school hour. & 84 & 2.10 & 0.45 & Reject \\
\hline
\end{tabular}

Table 1: Time Management Competencies of Enugu State Primary School Head teachers in Knowledge and Learning Management 
Analysis in table 1 above shows that the mean scores from item 1-14 were 1.85, 3.14, 2.75, 3.25, 2.84, 3.04, 2.71, $2.02,2.96,2.78,3.15,3.34,3.30$ and 2.10 respectively. Items 1,8 and 14 were rejected because their mean score is below 2.50. Other items were accepted because their mean score was 2.50 and above.

- $\quad$ Research Question Two: To what extent do Enugu state primary school head teachers practice time management competencies for knowledge and learning management?

\begin{tabular}{|c|c|c|c|c|c|}
\hline $\mathrm{S} / \mathrm{N}$ & ITEMS & $\mathbf{N}$ & $\overline{\mathbf{X}}$ & SD & Decision \\
\hline 1 & $\begin{array}{c}\text { Extent your head teacher mandate you to resume school on } \\
\text { time }\end{array}$ & 188 & 1.99 & 1.08 & Reject \\
\hline 2 & Extents your head teacher assign bell ringing to pupils. & 188 & 3.17 & 0.63 & Accept \\
\hline 3 & What extent do your head teacher rotate morning duty & 188 & 2.88 & 0.54 & Accept \\
\hline 4 & Extent you are notified on class punctuality & 188 & 2.32 & 0.48 & Reject \\
\hline 5 & $\begin{array}{l}\text { Extent your head teacher monitors teacher's endorsement of } \\
\text { signature on daily basis }\end{array}$ & 188 & 2.22 & 0.46 & Reject \\
\hline 6 & $\begin{array}{l}\text { Your head teacher monitors the school time table to suit } \\
\text { learning needs of pupils. }\end{array}$ & 188 & 2.88 & 0.54 & Accept \\
\hline 7 & $\begin{array}{l}\text { Extent your head teacher ensures that time for practicals and } \\
\text { time table do not conflict }\end{array}$ & 188 & 1.87 & 1.06 & Reject \\
\hline 8 & $\begin{array}{l}\text { What extent do your head teacher ensure that plays are only } \\
\text { done at break period }\end{array}$ & 188 & 2.90 & 0.54 & Accept \\
\hline 9 & $\begin{array}{c}\text { Extent head teachers are involved in regulating inflow of pupils } \\
\text { inside the school library }\end{array}$ & 188 & 1.85 & 1.05 & Reject \\
\hline 10 & $\begin{array}{c}\text { Extent your head teacher is involved in planning days children } \\
\text { visits school library }\end{array}$ & 188 & 2.09 & 1.46 & Reject \\
\hline 11 & Extent your head teacher timely provides school records & 188 & 3.19 & 0.63 & Accept \\
\hline 12 & Extent your head teacher is involved in internal supervision & 188 & 3.16 & 0.62 & Reject \\
\hline 13 & $\begin{array}{l}\text { Extent your head teacher timely maintains material resources } \\
\text { that aids teaching }\end{array}$ & 188 & 1.97 & 1.08 & Reject \\
\hline 14 & Extent your movement out of school is regulated. & 188 & 3.05 & 0.57 & Accept \\
\hline
\end{tabular}

Analysis in table 2 above shows that the mean scores from item 1-14 were 1.99, 3.17, 2.88, 2.32, 2.22, 2.88, 1.87, $2.90,1.85,2.09,3.19,3.16,1.97$ and 3.05 respectively. Items $1,4,5,7,9,10$, and 13 were rejected because their mean score is below 2.50. Other items were accepted because their mean score was 2.50 and above.

\subsection{Testing of Hypothesis}

\subsubsection{Hypothesis 1}

Male and female head teachers opinion on time management competencies of Enugu state primary school head teachers do not significantly aid knowledge and management of learning.

\begin{tabular}{|c|c|c|c|c|c|c|c|c|}
\hline Respondents & $\mathbf{N}$ & SD & $\mathbf{X}$ & t-cal & $\mathbf{d f}$ & $\boldsymbol{\alpha}$ & T-crit & Decision \\
\hline Female & 71 & 0.71 & 0.82 & & & & & \\
\hline & & & & 0.150 & 116 & .05 & 1.984 & Accept H0 \\
\hline Male & 13 & 0.35 & 0.21 & & & & & \\
\hline
\end{tabular}

On the table 3 above, t-cal (0.150) is less than t-crit (1.984). The null hypothesis is accepted.

\subsubsection{Hypothesis 2}

Male and female teachers' opinion do not significantly differ on extent head teacher's practice of competencies aids knowledge and management of learning.

\begin{tabular}{|c|c|c|c|c|c|c|c|c|}
\hline Respondents & $\mathbf{N}$ & SD & $\mathbf{X}$ & t-cal & df & A & T-crit & Decision \\
\hline Female & 160 & 3.41 & 1.61 & & & & & \\
\hline Male & & & & 2.542 & 186 & .05 & 1.972 & Reject Null Hypothesis \\
\hline
\end{tabular}


On the table 4 above, t-cal (2.542) is greater than t-crit (1.972), therefore the null hypothesis is rejected.

\section{Discussion}

Analysis in table one sought time management competencies of Enugu state primary school head teachers in knowledge and learning management. Findings reveal that head teachers assign role of ringing the school bell to particular pupils. Rotation of morning duties for teachers, notifying teachers on punctuality, insisting that staff endorse signature to indicate attendance were among the competencies primary school head teachers practice in Enugu State. Similarly, Idu (2004) reported that competencies that were part of head teachers in time management includes motivating teachers to arrive school on time and prepare their children to sweep classrooms. But Uche (2010) held that reasons head teachers monitor early morning activities in schools were because most teachers who earlier volunteered on this were lousy and left the duties uncoordinated. Hence, the need for the head teacher to personally supervise sensitive duties by giving teachers and pupils roles. Commenting on rotation of duty as part of time management competence of school heads, Ugwulashi (2012) held that head teachers were involved on this is to ensure that duty roaster followed by concerned teachers. In this case, involved teachers were to monitor pupils sweeping the school compound, sweep their classrooms, throw away bin etc. before devotion.

Identifying with teacher's punctuality by head teachers, Abid, Saghir and Ayesha (2018) observed in his study that punctuality was highly observed in schools head teachers where punctual and active in duty but maintained that teacher's attendance register were necessary for evidence during supervision. Attendance as discovered were also necessary to help identify teachers that were present in school on daily basis.

Other competencies include appropriate placement of subjects on timetable, ensure that teachers schedule of practical class tallies with time table, regulating and rotating influx of pupils inside the school library, timely providing teachers with needed records, head teacher involvement in internal supervision, timely maintenance of material resources to aid learning and regulating teachers' movement during school hours. These findings were in consonant with Leonard (2010) and Hallinger (2013).

Leonard (2010) suggested elongation of periods allocated for practical class as most times, teachers encroach into other lesson period. He reveals that most libraries in primary schools are inadequate. Owing the fact that they are not spaced enough to accommodate large number of pupils. Most time, the library is locked by orders from the school head and opened based on strict conditions.

These findings agree with Hallinger (2013) discovered that most schools regulate number of student that influx the library to maintain standard. In line with the findings of this research that time management of head teachers include early provision of recording materials, Onyemerekeya (2008) noted that supported head teachers involvement in provision of school records, provision and maintenance of instructional materials where to make the work of the teacher easy, fast and to make learning interesting. Anuna (2006) commenting on supervision, warns that head teacher must adopt supervisory techniques that carry every teacher along instead of scaring them away.

Research question two sought extent Enugu State primary school head teachers practice time management competence for knowledge and learning management. Findings show that to a high extent, head teachers assign ringing of bell to selected pupils, rotates morning duty, monitors tie table to suit learning. Ensure play are done at break period. Ugwulashi (2012) differs on this. He noted that most times, junior teachers were assigned such roles including notifying lesson periods through bell ringing. Most of these teachers were free to relegate this assignment to pupils. Dike (2010) identified that managing duty roaster is part of the head teacher's managerial responsibility but suggest that head teachers should always consult with teachers to avoid ins disciplinary behaviours. Dike also insisted that teachers should monitor periods of lessons and report he ways pupils responds to instructions. His reason was that children missed important lessons at first and second periods on daily basis due to lateness to school. They also get tired and feel passive towards dismiss hours of schools; hence, motor activities be integrated at periods teachers observe pupils are passive.

\section{Recommendations}

Based on the findings from this research, the followings were recommended.

- Head teachers should be consistent in management of time in their schools as this will be emulated by teachers to ensure that learning is effectively managed in the $21^{\text {stcentury. }}$

- Head teachers should as well monitor teachers he assigned duties to ensure that they were implemented on time.

- Primary school head teachers should ensure that they involve teachers in their academic plan as this will help reduce the possibility of delays in implementation of educational policies in school.

\section{References}

i. Abid, H. C., Sagihir, A and Ayesha, B (2018) Head teacher as an instructional leader in school. Bulletin pf education and Research. 40, (1) 77-87.

ii. Abiogu, G. (2014). Philosophy of education: A tool for national development? Open Journal of Philosophy, 4(3), 372-377.

iii. Chiaha, G.T.U (2013). Teacher-principal communication patterns as correlates of effective school administration in public secondary schools in Onitsha education zone of Anambra State. Unpublished P. hD Thesis, department of Educational Foundations, University of Nigeria, Nsukka.

iv. Fedl Republic of Nigeria (FRN). (2004). Implementation Guidelines for the Universal Basic $\quad$ Education $(U B E)$ Programme (p.17). Abuja: Fedl Ministry of Education. 
v. Hallinger, P (2013). A conceptual framework for reviews of research in educational leadership and management. Journal of Educational Administration, 49, 125-241

vi. Idu, A.P (2004). Introduction in educational management and supervision. Owerri/Onitsha/Lagos: Cape Publishers Int. Ltd

vii. Jason, G, Susanna, l. and Hajime, M (2015). Principle time management skills: patters in principles time use, jobs stress and perceived effectiveness. Journal of Educational Administration 53 (6) 773-793.

viii. Leomard, J (2010). framing the issues of the principal time. In finding the time for instructional leadership: management strategies for strengthening the academic program. Lanham: Rowman \& Littlefield education

ix. Lydiah, L. M and Nasongo, J. W. (2009). Role of the Head teacher in Academic achievement in secondary schools in Vihiga District, Kenya. Current Research Journal of Social Sciences 1 (3) 84-92

X. Uche, C.M (2010). Different ways and methods of developing individuals in an organization. Port Harcourt; University of Port Harcourt Press.

xi. Ugwulashi, C.S (2012). Time management and school administration in Nigeria: problems and prospects. Proceedings of the i1s international technology, education and environment conference. African society for scientific research.

xii. Zafarillah, S., Mumtaz, K., Uzma, M. P., Abida, S, and Hum, S. (2016). Teacher's time management and the performance of students: a comparison of government and private schools of Hydbad, Sindh, Pakistan. World Journal of Education, 6(6), 42-50 